\title{
A report on physical performance in female patients diseased for idiopathic scoliosis
}

\author{
Maria Laurentowska ${ }^{1}$, Ewa Szczepanowska ${ }^{1}$, \\ Maciej Glowacki ${ }^{2}$, Tadeusz Rychlewski ${ }^{1}$ \\ ${ }^{1}$ Chair of Physiology, Biochemistry and Hygiene, University School of Physical Education, \\ Królowej Jadwigi 27/39, 61-871 Poznań, Poland; E-mail: rychlew@awf.poznan.pl \\ ${ }^{2}$ W. Dega Independent Public Clinic No 4, ul. 28 Czerwca 1956, 61-544 Poznań
}

\begin{abstract}
The purpose of this study was to examine physical performance and exercise tolerance in patients with scoliosis in comparison with healthy girls of the similar age. Results of the study show the similar aerobic performance in both groups. However, exercise tolerance was significantly lower in patients with scoliosis than in the control group. Similarly, resting values of cardiac output and stroke volume were significantly lower in girls with scoliosis as compared with healthy girls.

KEY WORDS adolescents, exercise testing, lateral spinal curvature, physical effort

Prz. Antropol. - Anthropol. Rev. (2001), vol. 64, pp. 109-114, Tables 3. ISBN 8386969-64-4, ISSN 0033-2003
\end{abstract}

\section{Introduction}

In an overwhelming number of cases scolioses (lateral spinal curvature) are of an idiopathic character. There are many hypotheses about the genesis of scoliosis, but none of them completely explains the cause of these diseases - only $10-20 \%$ cases of scoliosis are explained by known determinants. The basic significance in the development of these diseases is often arrogated to developmental disturbances of vertebral augmented cartilages, ribs and spinal ligaments. Other studies, however, report these factors to be a secondary phenomenon, whereas, the disorders of muscle balance that result from changes in the nervous system being the primary one. In electromyographical studies of scolioses significant differences in electrical muscle activity at both sides of spine are shown [CAŁKA-LIZIS 1990]. Thorough genetic assessments indicated hereditary characters of these diseases [MitrosZEWSKA 1983].

Idiopathic scolioses develop only in children and adolescents who are in a growth period. These scolioses occur more often in girls than in boys, and 
more frequently are rightward by their protuberance. Patients suffering from lateral idiopathic spinal curvature are characterized by lower body mass and lower body height than their peers [MitrosZEWSKA 1983]. This effect results from negative nitrogen balance present in heavier, quickly progressing scolioses.

Scolioses disfigure the patients, and in advanced forms impair both physical performance and - mental efficiency, thus shortening their life. Lateral spinal curvature is recognized as a disease of the entire body. Besides complex changes in the locomotor system the changes in internal organs also appear [KASPERCZYK 1988]. They result in a lowering of the patients' physical ability, deteriorating the quality of their life. With regard to a considerable frequency of scolioses occurrence, the disease has become not only a therapeutic, but also a socioeconomical problem. It seems useful, then, to supplement standard studies of idiopathic scolioses treatment by the evaluation of general physical performance of patients. These studies will allow the administering of the adequate treatment to improve physical performance.

The aim of this study is to evaluate physical performance and exercise tolerance in girls suffering from lateral idiopathic spinal curvature in comparison with healthy girls of the similar age.

\section{Materials and methods}

Two groups of girls were examined. The first one, was the group of patients with lateral idiopathic spinal curvature $(\mathrm{N}=42)$. The average angle value of scoliosis measured by Cobb [PIĄTKOWSKI 1990] was about $50^{\circ}$. The second one - the control group included healthy girls $(\mathrm{N}=22)$. Anthropometric data in both groups are shown in Table 1 .

In order to evaluate their exercise tolerance, the girls from both groups performed a graded exercise on cycloergometer. The initial load commenced at $25 \mathrm{~W}$, and then every 3 minutes the load was increased by $25 \mathrm{~W}$. The exercise was finished directly after the appearance of ventilatory threshold (VT). This threshold was determined by functional parameters of circulatory and respiratory systems. Parameters were recorded continuously during exercise testing by $\mathrm{CardiO}_{2}$ set with Cardio-Pulmonary Exercise Graphics Corporation computer system (USA). The blood samples were taken from patients' fingertips before exercise, and 3 minutes after the test in order to determine acid-base balance parameters by AVL $995 \mathrm{Hb}$ apparatus and lactic acid by enzymatic method.

Maximal oxygen uptake was determined by indirect method of AstrandRhyming nomogram based on linear relation between oxygen uptake and

Table 1. Anthropometric characteristics of two examined groups

\begin{tabular}{lcccccc}
\hline \multirow{2}{*}{ Parameter } & \multicolumn{2}{c}{ Patients $(\mathrm{N}=42)$} & & \multicolumn{2}{c}{ Control group $(\mathrm{N}=22)$} \\
\cline { 2 - 3 } \cline { 5 - 7 } & mean & $\mathrm{SD}$ & & mean & SD \\
\hline Age (years) & 13.6 & 1.2 & & 14.1 & 0.2 \\
Body mass $(\mathrm{kg})^{*}$ & 45.8 & 5.9 & & 58.8 & 11.2 \\
Body height $(\mathrm{cm})^{*}$ & 159.6 & 7.1 & & 164.2 & 5.1 \\
\hline
\end{tabular}

* Statistically significant difference between groups $(\mathrm{p}<0.01)$ 
heart rate [ASTRAND and RHYMING 1954]. During a resting condition stroke volume was determined by carbon dioxide method using the above mentioned $\mathrm{CardiO}_{2}$ apparatus. Basic statistical methods were used to work out the obtained results. The significance of differences was calculated by the MannWhitney test.

\section{Results}

The absolute mean value of maximal oxygen uptake $\left(\mathrm{VO}_{2} \max \right)$ in girls with scoliosis was slightly lower than in the control group, whereas, the relative value of this parameter (calculated per kilogram of body mass) was significantly higher in patients (see Tab. 2).

Both stroke volume and cardiac output, measured while at rest, were significantly lower $(\mathrm{p}<0.01)$ in girls with the lateral idiopathic spinal curvature (Tab. 2). The relative value of cardiac output, calculated per kilogram of body mass, was lower in the group of patients. Table 2 also shows the values of studied pa- rameters of both groups at the moment of the ventilatory threshold. The achieved power was similar in patients and in healthy girls. However, girls from the control group performed somewhat greater work. Heart rate accompanying the ventilatory threshold was significantly lower than in the control group $(\mathrm{p}<0.05)$. Patients obtained a significantly higher relative value of oxygen uptake at the moment of the ventilatory threshold, which was also the higher percent value of maximal oxygen uptake.

The worse adaptation to exercises in the patient group can be explained by greater participation of anaerobic processes in covering energy supply of organism (Tab. 3). This is shown by the significantly higher value of the lactic acid concentration after exercise and also the higher difference between postexercise and pre-exercise values. A significantly higher post-pre-exercise value of basic excess $(\mathrm{p}<0.01)$ was also observed. The value of blood $\mathrm{pH}$ after exercise (the post-exercise value) in both groups remains in limits of the

Table 2. Mean values of physiological parameters obtained at the level of the ventilatory threshold in

\begin{tabular}{|c|c|c|c|c|}
\hline \multirow{2}{*}{ Parameter } & \multicolumn{2}{|c|}{ Patients } & \multicolumn{2}{|c|}{ Control group } \\
\hline & mean & SD & mean & SD \\
\hline Maximal oxygen uptake $\left(1 \times \min ^{-1}\right)$ & 1.99 & 0.28 & 2.17 & 0.35 \\
\hline Maximal oxygen uptake $\left(\mathrm{ml} \times \mathrm{kg}^{-1} \times \min ^{-1}\right)^{* *}$ & 44.33 & 7.88 & 38.44 & 9.38 \\
\hline Stroke volume $-\mathrm{V}_{\mathrm{S}}(\mathrm{ml})^{* *}$ & 56.31 & 21.44 & 73.69 & 15.99 \\
\hline Cardiac output $-\mathrm{Q}_{\mathrm{t}}(\mathrm{l}) * *$ & 4.37 & 1.44 & 6.10 & 1.08 \\
\hline Predicted cardiac output - Pred. $Q_{t}(1)$ & 5.88 & 0.63 & 6.06 & 0.64 \\
\hline$\Delta \mathrm{Q}_{\mathrm{t}}(\mathrm{l})$ & -1.46 & 1.19 & 0.04 & 0.70 \\
\hline Heart index $-\mathrm{Q}_{\mathrm{t}} \times \mathrm{kg}^{-1}(\mathrm{ml})$ & 95.08 & 33.00 & 111.07 & 20.87 \\
\hline Work $(J)$ & 27714.3 & 8791.7 & 30136.4 & 13190.2 \\
\hline Power (W) & 79.3 & 16.0 & 81.3 & 20.3 \\
\hline Heart rate - HR $\left(\right.$ beat $\left.x \min ^{-1}\right) *$ & 170.3 & 12.8 & 161.5 & 16.0 \\
\hline Oxygen uptake $-\mathrm{VO}_{2}\left(\mathrm{ml} \times \mathrm{kg}^{-1} \times \min ^{-1}\right) * *$ & 21.0 & 4.8 & 17.2 & 4.2 \\
\hline Percent of $\mathrm{VO}_{2} \max \left(\mathrm{ml} \times \mathrm{kg}^{-1} \times \mathrm{min}^{-1}\right) * *$ & 49.2 & 13.8 & 45.8 & 10.9 \\
\hline
\end{tabular}

* Statistically significant difference between groups $(\mathrm{p}<0.05)$

$* *$ Statistically significant difference between groups $(\mathrm{p}<0.01)$ 
Table 3. Mean values of blood acid-base balance parameters and the concentration of lactic acid obtained at the level of the ventilatory threshold in both groups

\begin{tabular}{|c|c|c|c|c|c|}
\hline \multirow{2}{*}{ Parameter } & & \multicolumn{2}{|c|}{ Patients } & \multicolumn{2}{|c|}{ Control group } \\
\hline & & mean & SD & mean & SD \\
\hline $\mathrm{pH}$ & $\begin{array}{l}\text { pre-exercise** } \\
\text { post-exercise* } \\
\Delta \mathrm{pH}\end{array}$ & $\begin{array}{l}7.38 \\
7.35 \\
0.03\end{array}$ & $\begin{array}{l}0.02 \\
0.03 \\
0.03\end{array}$ & $\begin{array}{l}7.36 \\
7.34 \\
0.02\end{array}$ & $\begin{array}{l}0.02 \\
0.02 \\
0.03\end{array}$ \\
\hline Lactic acid - LA (mmol) & $\begin{array}{l}\text { pre-exercise } \\
\text { post-exercise* } \\
\Delta \mathrm{LA}^{*}\end{array}$ & $\begin{array}{l}1.59 \\
3.39 \\
1.89\end{array}$ & $\begin{array}{l}0.42 \\
1.28 \\
1.23\end{array}$ & $\begin{array}{l}1.21 \\
2.48 \\
1.26\end{array}$ & $\begin{array}{l}0.26 \\
1.05 \\
1.00\end{array}$ \\
\hline Basic excess - BE (mmol) & $\begin{array}{l}\text { pre-exercise } \\
\text { post-exercise } \\
\Delta \mathrm{BE}^{* *}\end{array}$ & $\begin{array}{l}-1.11 \\
-4.16 \\
-3.00\end{array}$ & $\begin{array}{l}1.45 \\
2.15 \\
1.70\end{array}$ & $\begin{array}{l}-3.02 \\
-4.60 \\
-1.72\end{array}$ & $\begin{array}{l}1.59 \\
1.23 \\
1.95\end{array}$ \\
\hline $\begin{array}{l}\text { Partial oxygen pressure } \\
-\mathrm{pO}_{2}(\mathrm{mmHg})\end{array}$ & $\begin{array}{l}\text { pre-exercise } \\
\text { post-exercise } * * \\
\Delta \mathrm{pO}_{2} * *\end{array}$ & $\begin{array}{l}71.22 \\
83.78 \\
12.43\end{array}$ & $\begin{array}{l}6.09 \\
6.29 \\
7.53\end{array}$ & $\begin{array}{r}70.33 \\
73.97 \\
3.65\end{array}$ & $\begin{array}{l}7.63 \\
7.45 \\
8.87\end{array}$ \\
\hline $\begin{array}{l}\text { Partial carbon dioxide pressure } \\
-\mathrm{pCO}_{2}(\mathrm{mmHg})\end{array}$ & $\begin{array}{l}\text { pre-exercise } \\
\text { post-exercise } \\
\Delta \mathrm{pCO}_{2} * *\end{array}$ & $\begin{array}{r}40.47 \\
37.67 \\
2.66\end{array}$ & $\begin{array}{l}2.77 \\
2.35 \\
2.20\end{array}$ & $\begin{array}{r}39.15 \\
38.17 \\
0.73\end{array}$ & $\begin{array}{l}2.33 \\
2.28 \\
2.84\end{array}$ \\
\hline
\end{tabular}

* Statistically significant difference between groups $(\mathrm{p}<0.05)$

** Statistically significant difference between groups $(\mathrm{p}<0.01)$

physiological norm. This value shows the even character of the observed acidosis. Concurrently, statistically significant greater changes $(\mathrm{p}<0.01)$ under the influence of exercise in partial oxygen and carbon dioxide pressure in capillary blood are observed in girls with lateral idiopathic spinal curvature.

\section{Discussion}

Permanently diminishing physical activity is one of the determinants bringing about the posture defect development, including idiopathic scolioses [ZARZYCKI et al. 1998]. Scolioses, particularly of higher angle values $\left(60^{\circ}\right.$ and greater by Cobb), are accompanied by lowered general physical efficiency, and circulatory-respiratory performance as a result of lowering the general performance of the organism. Maximal oxygen uptake is traditionally considered to be the best parameter of aerobic performance evaluation. The efficiency of oxygen supply function is increased in children and adolescents up to 20 years of age. In the opinion of many scientists mean values of this parameter in girls aged 14 are observed on different levels: from 1.831 per minute to 2.581 per min. (see e.g., KOZŁOWSKI and NAZAR [1999]).

In our study, healthy girls attained $\mathrm{VO}_{2} \max$ equal to 2.171 per min., whereas patients - the value of 1.991 per minute. Therefore, aerobic performance of examined patients does not differ significantly from the performance of healthy girls. The predominant role in shaping maximal oxygen uptake is attributed to factors determinating the ability to supply the tissues with oxygen. Among these factors, the most significant is the value of cardiac output. The data based on literature show that 
scoliosis, particularly when it is of a progressing character, influences disadvantageously the function of the heart muscle. It is manifested in diminished stroke volume and cardiac output proportionally to the increase of scoliosis angle [ZARZYCKA et al. 1983]. In our studies we also noted the statistically significant lowering of these circulatoryrespiratory parameters measured in resting status in examined patients as compared with the control group.

The high correlation between maximal oxygen uptake and ventilatory threshold allows the use of this parameter to evaluate aerobic performance [HEBESTREIT et al. 2000; ROWLAND and GREEN 1988; REYBROUCK et al. 1985; COOPER et al. 1984]. The greater the intensity of exercise in achieving the ventilatory threshold the better the performance of the given person. Although the intensity of a threshold exercise in examined groups was similar, girls with lateral idiopathic spinal curvature were characterized by higher heart rates. This shows the worse exercise tolerance as compared with the healthy group. The exercise tolerance in healthy people depends on the physical performance characterized by maximal oxygen uptake. In patients, however, despite a significant physical performance evaluated on the base of $\mathrm{VO}_{2} \mathrm{max}$, the lower ability to perform exercise following the activity of pathologic factors can be observed.

The degree of the acid-base homeostasis disturbance at the load adequate to the ventilatory threshold is also a measure of physical performance. For patients with scoliosis, changes within acid-base balance blood parameters caused by exercise were significantly greater than in the control group. This is another confirmation of their lower exercise tolerance. However, in patients the hypoxia was not observed. The partial pressure of studied gases in the blood was normal. Disadvantageous changes of gas partial pressure in the blood appear more commonly at higher angle values of scoliosis [WIERUSZKOZŁOWSKA and KUBACKI 1983].

To sum up, the main points of this paper are as follows:

1. Aerobic performance in girls with scoliosis evaluated on the base of maximal oxygen uptake was similar to the value obtained by healthy girls.

2. Exercise tolerance of patients was significantly lower than in the control group.

3. Resting values of cardiac output and stroke volume were significantly lower in girls with lateral idiopathic spinal curvature as compared with the healthy group.

\section{References}

Astrand P.O., I. RhYMing, 1954, A nomogram for calculation of aerobic capacity (physical fitness) from pulse rate during submaximal work, J. Appl. Physiol., 9, 2-8

CAŁKA-Lizis T., 1990, Próba prognozowania $i$ ocena efektów rehabilitacji skolioz operowanych metoda Harringtona, Doctoral thesis, AWF Kraków

CoOper D., B. Weiler-RAVEl, B.J. Whipp, K. WASSERMANN, 1984, Aerobic parameters of exercise as a function of body size during growth in children, J. Appl. Physiol., 56, 628634

Hebestreit H., B. Stascgen, A. Hebestreit, 2000, Ventilatory threshold: a useful method to determine aerobic fitness in children?, Medicine in Sport Exercise, 32, 1964-69

KASPERCZYK T., 1988, Postawa ciała a wybrane cechy morfologiczne $i$ funkcjonalne $u$ dzieci w wieku 8-15 lat, AWF Kraków 
KoZŁowsKi S., K. NAZAR, 1999, Wprowadzenie do fizjologii klinicznej, PZWL, Warszawa

MitroszewSKA H., 1983, Charakterystyka skoliozy idiopatycznej, [in:] Wczesne wykrywanie $i$ zapobieganie progresji bocznych skrzywień kregostupa, Sesja PAN, Poznań 1980, PZWL, Warszawa, pp. 67-68

PiĄTKOWSKI S, 1990, Ortopedia, traumatologia i rehabilitacja narzadów ruchu, PZWL, Warszawa

Reybrouck T., M. Weymans, H. Stijns, L. Van DER HAUWAERT, 1985, Ventilatory anaerobic threshold in healthy children, Eur. J. Appl. Physiol., 54, 278-284

Rowland T.W., G.M. Green, 1988, Physiological responses to treadmill exercise in females' adult-child differences, Med. Sci. Sports Exerc., 20, 474-478
WiERUSZ-KozŁowsKa M., A. KuBACKI, 1983, Ocena czynności uktadu oddechowego u chorych z bocznym idiopatycznym skrzywieniem kręostupa oraz rola leczenia operacyjnego, [in:] Wczesne wykrywanie i zapobieganie progresji bocznych idiopatycznych skrzywień kręgostupa, Sesja PAN, Poznań 1980, PZWL, Warszawa, pp. 299-304

ZARZYCKA M., D. ZARZYCKI, T. PAŁKO, J. DoBrogowski, 1983, Wptyw bocznego idiopatycznego skrzywienia kręostupa na wentylacje i ukrwienie pluc, [in:] Wczesne wykrywanie $i$ zapobieganie progresji bocznych idiopatycznych skrzywień kręgostupa, Sesja PAN, Poznań 1980, PZWL, Warszawa, pp. 183-185

ZARZYCKI D., K. BRZOZOWSKI, T. SNAKOWSKI, 1998, Wartość testu Rissera w ocenie progresji skolioz idiopatycznych, Postępy Rehabilitacji, XII, 5-11

\section{Streszczenie}

Celem pracy była ocena wydolności fizycznej oraz tolerancji wysiłkowej dziewcząt chorujących na idiopatyczne boczne skrzywienia kręgosłupa (skoliozy) w porównaniu z dziewczętami zdrowymi będącymi w podobnym wieku. Do oceny tolerancji wysiłkowej zastosowano próbę wysiłkową o wzrastającej intensywności na ergometrze rowerowym. Test wysiłkowy kończono bezpośrednio po wystąieniu progu wentylacyjnego, który wyznaczany był przy użyciu zestawu komputerowego $\mathrm{CardiO}_{2}$ firmy MedGraphics.

Przed przystapieniem do testu oraz 3 min. po jego ukończeniu pobierano krew włośniczkową $\mathrm{w}$ celu oznaczenia parametrów równowagi kwasowo-zasadowej krwi aparatem AVL $995 \mathrm{Hb}$ i stężenia kwasu mlekowego metodą enzymatyczną. W warunkach spoczynkowych wyznaczono rzut serca (metodą dwutlenkowęglowa) posługując się zestawem $\mathrm{CardiO}_{2}$. Wyznaczono maksymalny pobór tlenu przy użyciu nomogramu Astrand-Rhyming. Uzyskane wyniki badań wskazują na podobną wydolność tlenową pacjentek i dziewcząt zdrowych ocenianą na podstawie maksymalnego poboru tlenu. Natomiast tolerancja wysiłkowa badanej grupy pacjentek była istotnie niższa niż w grupie kontrolnej (patrz tab. 2 i 3). Podobnie spoczynkowe wartości objętości minutowej i wyrzutowej serca były istotnie niższe u dziewcząt chorujących na skoliozy idiopatyczne, w porównaniu z grupą zdrową. 